\title{
Removal of Uranium from Spent Salt from the Molten Salt Oxidation Process
}

\author{
Leslie Summers \\ Peter C. Hsu \\ Erica von Holtz \\ David Hipple \\ Francis Wang \\ Martyn Adamson
}

March 1997

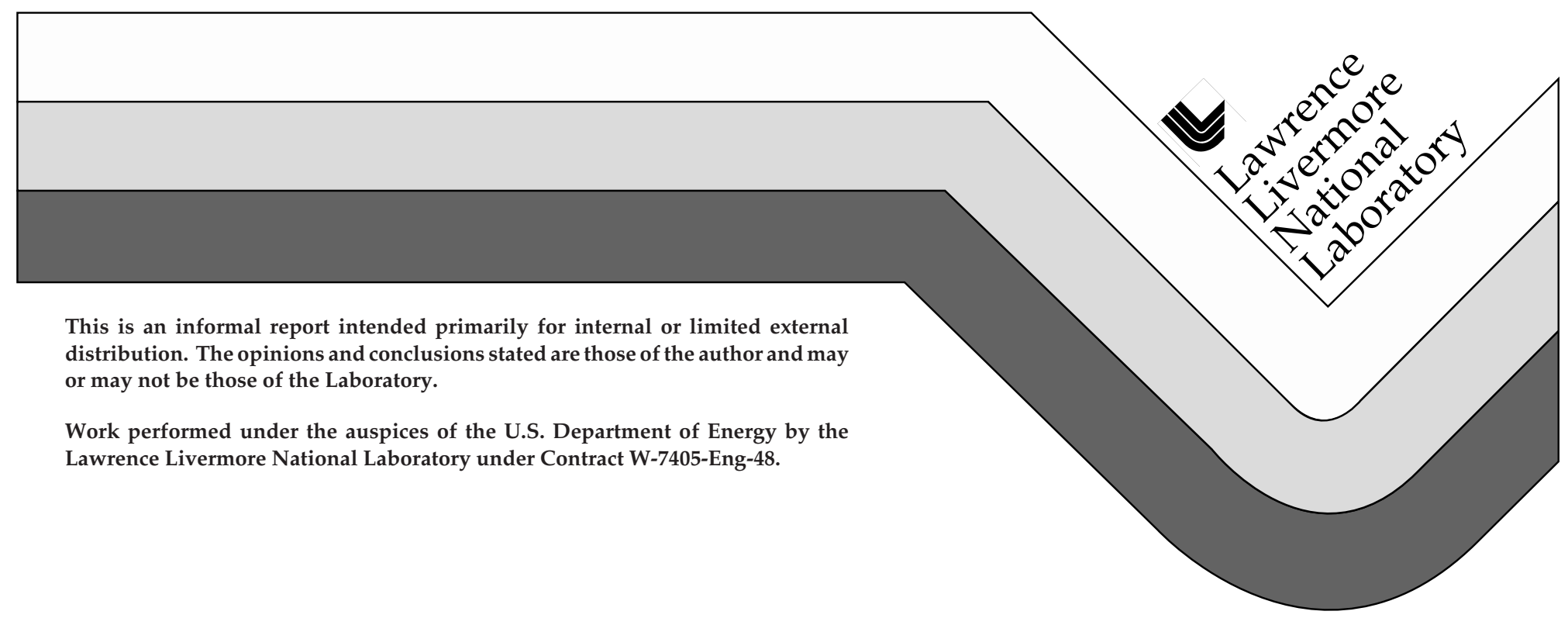




\section{DISCLAIMER}

This document was prepared as an account of work sponsored by an agency of the United States Government. Neither the United States Government nor the University of California nor any of their employees, makes any warranty, express or implied, or assumes any legal liability or responsibility for the accuracy, completeness, or usefulness of any information, apparatus, product, or process disclosed, or represents that its use would not infringe privately owned rights. Reference herein to any specific commercial product, process, or service by trade name, trademark, manufacturer, or otherwise, does not necessarily constitute or imply its endorsement, recommendation, or favoring by the United States Government or the University of California. The views and opinions of authors expressed herein do not necessarily state or reflect those of the United States Government or the University of California, and shall not be used for advertising or product endorsement purposes.

This report has been reproduced directly from the best available copy.

Available to DOE and DOE contractors from the Office of Scientific and Technical Information

P.O. Box 62, Oak Ridge, TN 37831

Prices available from (615) 576-8401, FTS 626-8401

Available to the public from the

National Technical Information Service

U.S. Department of Commerce 5285 Port Royal Rd.,

Springfield, VA 22161 


\title{
Removal of Uranium from Spent Salt from the Molten Salt Oxidation Process
}

\author{
Leslie Summers, Peter C. Hsu, Erica von Holtz, \\ David Hipple, Francis Wang, and Martyn Adamson \\ University of California \\ Lawrence Livermore National Laboratory \\ Livermore, California 94550
}

\section{Introduction}

Molten salt oxidation (MSO) is a thermal process that has the capability of destroying organic constituents of mixed wastes, hazardous wastes, and energetic materials. In this process, combustible waste and air are introduced into the molten sodium carbonate salt . The organic constituents of the waste materials are oxidized to carbon dioxide and water, while most of the inorganic constituents, including toxic metals, minerals, and radioisotopes, are retained in the molten salt bath. As these impurities accumulate in the salt, the process efficiency drops and the salt must be replaced. An efficient process is needed to separate these toxic metals, minerals, and radioisotopes from the spent carbonate to avoid generating a large volume of secondary waste. Toxic metals such as cadmium, chromium, lead, and zinc etc. are removed by a method described elsewhere. This paper describes a separation strategy developed for radioisotope removal from the mixed spent salt, as well as experimental results, as part of the spent salt cleanup.

As the MSO system operates, inorganic products resulting from the reaction of halides, sulfides, phosphates, metals and radionuclides with carbonate accumulate in the salt bath. These must be removed to prevent complete conversion of the sodium carbonate, which would result in eventual losses of destruction efficiency and acid scrubbing capability. There are two operational modes for salt removal: (1) during reactor operation a slip-stream of molten salt is continuously withdrawn with continuous replacement by carbonate, or (2) the spent salt melt is discharged completely and the reactor then refilled with carbonate in batch mode. Because many of the metals and/or radionuclides captured in the 
salt are hazardous and/or radioactive, spent salt removed from the reactor would create a large secondary waste stream without further treatment. A spent salt clean up/recovery system is necessary to segregate these materials and minimize the amount of secondary waste. These materials can then be encapsulated for final disposal.

\section{Uranium Removal by Chemical Reduction and Precipitation}

When the concentration of carbonate in the spent salt is low (as in mode 2) most of the mineral residues or metal species have limited solubility (if the $\mathrm{pH}$ is still >8) and will precipitate as metal oxides or hydroxides. The precipitation can be enhanced by $\mathrm{NaSH}$ which forms sulfides of the mineral species, thereby further reducing the solubility ${ }^{1}$. The addition of other reagents may be required to convert the valence state of dissolved metals into insoluble forms. Dithionite $\left(\mathrm{Na}_{2} \mathrm{~S}_{2} \mathrm{O}_{4}\right)$ reduces soluble $\mathrm{Cr}^{+6}$ to $\mathrm{Cr}^{+3}$, forming insoluble $\mathrm{Cr}(\mathrm{OH})_{3} / \mathrm{Cr}_{2} \mathrm{O}_{3}$ which has low solubility in alkaline solutions. Dithionite will also reduce uranium (VI) to uranium (IV), which is insoluble, and precipitates. The precipitated U(IV) can be removed by filtration. The following equation describes this reaction:

$$
\mathrm{S}_{2} \mathrm{O}_{4}^{-2}+3 \mathrm{UO}_{2}\left(\mathrm{CO}_{3}\right)_{3}^{-4}+8 \mathrm{OH}^{-} \leftrightarrow 9 \mathrm{CO}_{3}^{-2}+2 \mathrm{SO}_{4}^{-2}+3 \mathrm{UO}_{2} \downarrow+4 \mathrm{H}_{2} \mathrm{O}
$$

The results from experiments using dithionite $\left(\mathrm{Na}_{2} \mathrm{~S}_{2} \mathrm{O}_{4}\right)$ to precipitate uranium from low carbonate solution, at room temperature, are shown below in Table 1: (Uranium concentration was measured using ICP-MS).

Table 1:

Exp. \#: $\quad \underline{\text { Initial U conc. } \quad \underline{U} \text { conc. after Dithionite }}$ $\underline{\text { treatment }}$

U Red $1 \quad 164$ ppm $\quad 0.235$ ppm

U Red $2220 \mathrm{ppm} \quad 0.790 \mathrm{ppm}$

In the presence of 50 mole $\%$ (65 wt $\%$ ) $\mathrm{Na}_{2} \mathrm{CO}_{3}$ the dithionite is ineffective in reducing $\mathrm{U}(\mathrm{VI})$ to $\mathrm{U}(\mathrm{IV})$, as the experimental results in Table 2 show: 
Table 2:

Exp. \#: $\quad \underline{\text { Initial U conc. } \quad \underline{U} \text { conc. after Dithionite }}$ $\underline{\text { treatment }}$

U Red 32568 ppm $\quad 2313$ ppm

Radionuclides such as uranium form a highly soluble complex in carbonate solutions. Treatment with alkali $(\mathrm{NaOH})$ forms an insoluble sodium diuranate $\left(\mathrm{Na}_{2} \mathrm{U}_{2} \mathrm{O}_{7}\right)^{2}$ which is recovered by filtration, yielding ppm levels of uranium in solution. The carbonate solution is then dried and recycled back to the MSO reactor for reuse. If the spent salt contains low levels of carbonate and is destined for disposal, the uranium can be removed by a chemical reduction method (such as dithionite or $\mathrm{NaSH}$ ), similar to that used for metals precipitation ${ }^{3}$. Any residual uranium in solution is further removed using an ion exchange resin, Diphonix ${ }^{\circledR}$, which has a high selectivity for uranium over a specific $\mathrm{pH}$ range. This paper summarizes the experiments demonstrating the alkali treatment technique to reduce uranium concentrations to $50 \mathrm{ppm}$ levels, and the use of an ion exchange resin to reduce the uranium further to sub ppm levels.

The dissolved spent salt from the molten salt reactor, in the presence of carbonate and oxygen, contains uranium in the hexavalent (uranyl) state as sodium uranyl tricarbonate.

$\mathrm{UO}_{2}++3 \mathrm{CO}_{3}-2=\left[\mathrm{UO}_{2}\left(\mathrm{CO}_{3}\right) 3\right]^{-4}$

Under these conditions, at a $\mathrm{pH}$ of about 10-12, many elements are precipitated as hydroxides or carbonates ( $\mathrm{Fe}, \mathrm{Mn}, \mathrm{Al}, \mathrm{Pb}, \mathrm{Ca}$ ) while uranium remains in solution as the highly soluble sodium uranyl tricarbonate complex ${ }^{4}$. Using techniques derived from early uranium refining techniques we discovered that uranium is precipitated by the addition of sodium hydroxide. When the hydroxyl ion concentration becomes great enough, $(\mathrm{pH}>11)$ or an excess of sodium hydroxide of about five grams per liter, sodium diuranate will precipitate: 5

$2 \mathrm{UO} 2(\mathrm{CO} 3) 3^{4-}+6 \mathrm{OH}^{-}+2 \mathrm{Na}^{+}=\mathrm{Na}_{2} \mathrm{U}_{2} \mathrm{O}_{7} \downarrow+6 \mathrm{CO}_{3}^{-2}+3 \mathrm{H}_{2} \mathrm{O}$ 
The following test results in Table 3 illustrate the removal of uranium by the addition of $\mathrm{NaOH}$ to a 50 mole percent $\mathrm{Na}_{2} \mathrm{CO}_{3}, \mathrm{NaCl}$ solution.

Table 3:

Initial U conc. $\quad \underline{\mathrm{U} \text { conc. after }} \quad \underline{\mathrm{U} \text { conc. after }}$ $\underline{\mathrm{NaOH} \text { to } \mathrm{pH} 12.5} \quad \underline{\mathrm{NaOH} \text { to } \mathrm{pH} 13.2}$

$2453 \mathrm{ppm} \quad 190.51 \mathrm{ppm} \quad 46.7 \mathrm{ppm}$

Further uranium removal is accomplished using an ion exchange resin, specific for uranium.

\section{Ion Exchange for Uranium Removal}

Several ion exchange resins were evaluated for efficiency of uranium removal; Diphonix ${ }^{\circledR}$ (developed by Eichrom Industries, Inc.) ${ }^{6}$, and NaTiO (from Boulder Scientific, Inc.). Initial efficiency tests were performed by placing $0.1 \mathrm{~g}$ of test resin in a $20 \mathrm{cc}$ syringe, (loading capacity of $20 \%$ ). A kynar frit (30 um porosity) was placed at the bottom of each syringe. Each syringe, containing $20 \mathrm{ml}$. of test solution, was placed on a rotator/mixer at $1 \mathrm{rev} / 4 \mathrm{sec}$. The $\mathrm{pH}$ of each test solution was adjusted, using $\mathrm{HCl}$, to 5.5 (the recommended optimum) prior to contact with each resin. The results are displayed in Table 4.

Table 4:

Experiments at $\mathrm{pH} 5.5$ :

(exp. \#'s IE-4,5)

\begin{tabular}{llll}
$\frac{\text { \% Column }}{\text { Loading* }}$ & $\underline{\text { Initial U }}$ & $\underline{\text { U conc. after }}$ & $\underline{\text { U conc.after }}$ \\
\hline Diphonix & $\underline{\text { NaTiO }}$
\end{tabular}

$\begin{array}{llll}20 & 0.8 \mathrm{ppm} & 0.10 \mathrm{ppm} & -- \\ 20 & 1.2 \mathrm{ppm} & 0.12 \mathrm{ppm} & 6.5 \mathrm{ppm} \\ 40 & 4.7 \mathrm{ppm} & 0.38 \mathrm{ppm} & 30.1 \mathrm{ppm} \\ 80 & 76.9 \mathrm{ppm} & 0.52 \mathrm{ppm} & 10.3 \mathrm{ppm}\end{array}$

* Diphonix loading capacity is $40 \mathrm{mg} / \mathrm{g}$ resin 
The above results (Table 4) reflect the resin performance at the recommended optimum $\mathrm{pH}$ (5.5). We also evaluated each resin using the same protocol as described above, at $\mathrm{pH} 10.0$, to measure the resin performance at a $\mathrm{pH}$ closer to that of the filtrate following $\mathrm{NaOH}$ treatment.

\section{Table 5:}

Experiments at $\mathrm{pH} 10.0$ :

Exp. \#: $\quad$ Initial U conc.

$$
\underline{\mathrm{U} \text { conc. after }} \quad \underline{\mathrm{U} \text { conc. after }}
$$

$\underline{\underline{\text { Diphonix }}} \quad \underline{\mathrm{NaTiO}}$

$\begin{array}{lrlrlrl}\text { IE-8 } & 51.1 & \mathrm{ppm} & 29.8 & \mathrm{ppm} & 38.6 & \mathrm{ppm} \\ \text { IE-4 } & 86.7 & \mathrm{ppm} & 69.1 & \mathrm{ppm} & 80.5 & \mathrm{ppm} \\ \text { IE-4 } & 179.8 & \mathrm{ppm} & 150.0 & \mathrm{ppm} & 160.4 & \mathrm{ppm}\end{array}$

Diphonix ${ }^{\circledR}$ resin has much better affinity for uranium than does NaTiO, and as expected the affinity is better at the optimum $\mathrm{pH}$ of 5.5. The Diphonix ${ }^{\circledR}$ resin was then tested (using the same protocol as above) at $\mathrm{pH}$ 7.0 and 8.5 to evaluate the affinity at $\mathrm{pH}$ 's just above optimum. The results are shown in Table 6.

Table 6: (data from Exp IE-7)

\begin{tabular}{|c|c|c|}
\hline $\mathrm{pH}$ & $\underline{\text { Initial U conc. }}$ & $\frac{\text { U conc. after }}{\text { Diphonix } \AA}$ \\
\hline 7.0 & $41.9 \mathrm{ppm}$ & $3.7 \mathrm{ppm}$ \\
\hline & $85.0 \mathrm{ppm}$ & $3.9 \mathrm{ppm}$ \\
\hline & $165.0 \mathrm{ppm}$ & $8.8 \mathrm{ppm}$ \\
\hline & $41.6 \mathrm{ppm}$ & $13.5 \mathrm{ppm}$ \\
\hline & $85.0 \mathrm{ppm}$ & $15.8 \mathrm{ppm}$ \\
\hline & $170.0 \mathrm{ppm}$ & $58.3 \mathrm{ppm}$ \\
\hline
\end{tabular}

As the above results indicate, the affinity of Diphonix ${ }^{\circledR}$ resin for uranium, above the optimum $\mathrm{pH}$ of 5.5, is still relatively good. 
Table 7 and Figure 1 summarize the effect of solution $\mathrm{pH}$ on the uranium removal efficiency with Diphonix ${ }^{\circledR}$ resin. Optimal performace of the resin occurs at $\mathrm{pH} 5.5$.

\section{Table 7:}

Initial U conc. (ppm)

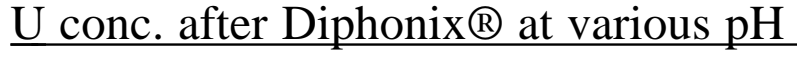

(ppm)

$$
46.1
$$

$(41.2 \sim 51.1)$

85.7

$(84.7 \sim 86.7)$

170.0

(160.0 170.0)

$\underline{5.5}$

7.0

8.5

3.7

13.5

29.8

0.12

0.38

3.9

15.8

69.1

0.52

8.8

58.3

150.0

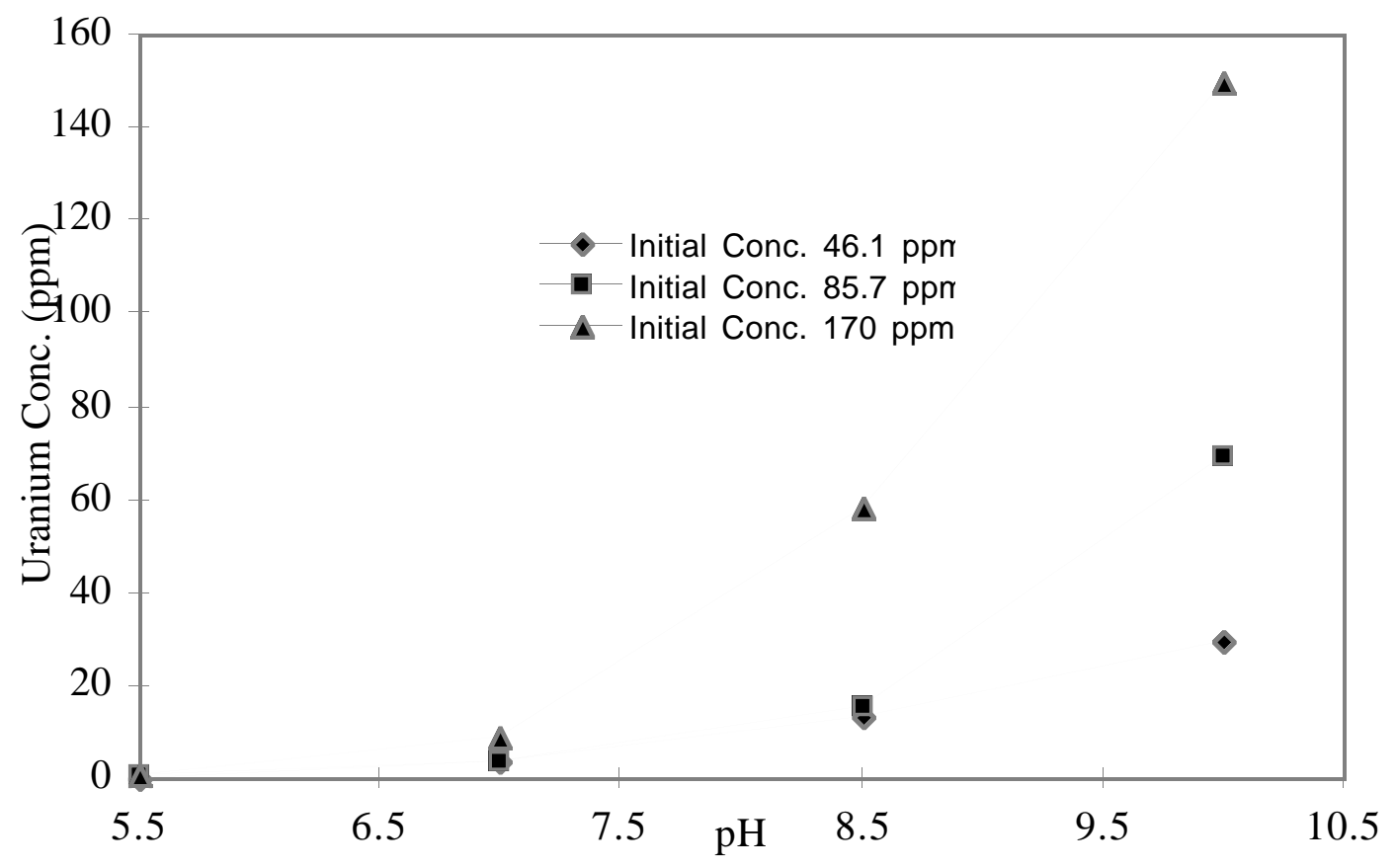

Fig. 1. Effect of Solution pH on Uranium Removal Efficiency with Diphonix ${ }^{\circledR}$ Resin 


\section{Diphonix Resin ${ }^{\circledR}$ for Uranium Removal in a Circulating System}

Using the information obtained in the preceding experiments we then designed several experiments to test the affinity of Diphonix ${ }^{\circledR}$ in a set up similar to that designed for the MSO pilot plant. The Diphonix ${ }^{\circledR}$ is placed in an ion exchange column and the test solution is pumped around at a particular rate. Periodically, grab samples are removed from the feed tank to measure concentration (by ICP-MS). Over time, the uranium concentration in the feed tank should decrease, as uranium is removed by the column. The schematic for this set up is shown below:

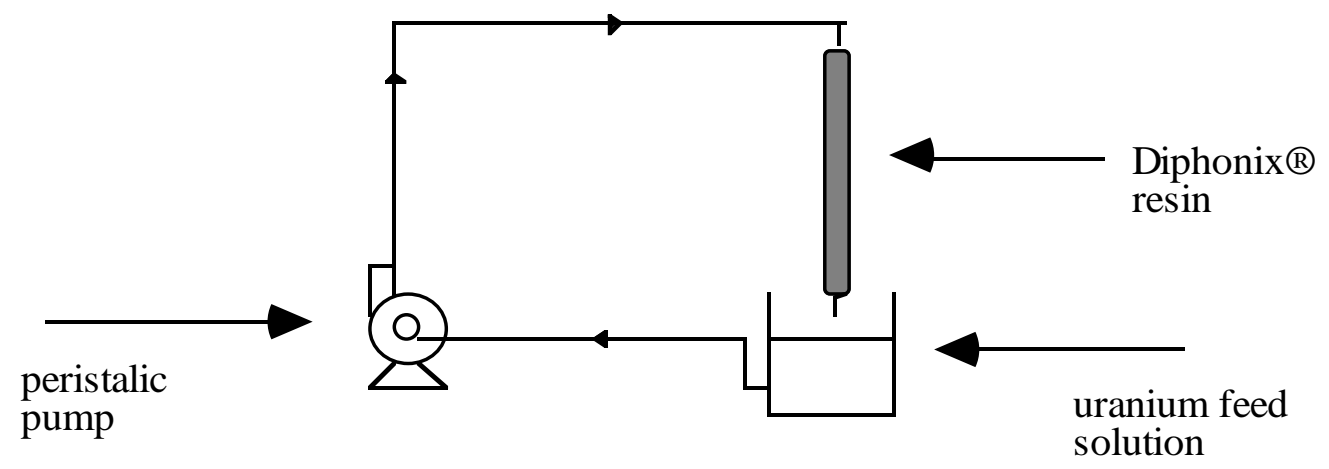

Fig. 2 Uranium removal using Diphonix ${ }^{\circledR}$ resin

Below (in Table 8) are the results of experiments modeling the pilot plant design, in which a carbonate free uranium feed solution (at a starting concentration of $\sim 150 \mathrm{ppm}$ ) is pumped through the ion exchange column containing Diphonix ${ }^{\circledR}$ at a flow rate of $30 \mathrm{cc} / \mathrm{min}$ and $10 \mathrm{cc} / \mathrm{min}$, loading of $16 \%$, and a $\mathrm{pH}$ of 5.5 . 


\section{$\underline{\text { Table } 8}$}

\begin{tabular}{ccc} 
Time & \multicolumn{2}{c}{ Uranium conc. (ppm) } \\
\cline { 2 - 3 } $0 \mathrm{hr}$ & $146 \mathrm{cc} / \mathrm{min}$ & @ $10 \mathrm{cc} / \mathrm{min}$ \\
$1 \mathrm{hr}$ & 58 & 144 \\
$2 \mathrm{hr}$ & 43 & 61 \\
$3 \mathrm{hr}$ & 35 & 39 \\
$4 \mathrm{hr}$ & 29 & 30 \\
$5 \mathrm{hr}$ & 26 & 26 \\
$6 \mathrm{hr}$ & & 24 \\
$8 \mathrm{hr}$ & 20 & 23 \\
$10 \mathrm{hr}$ & & 22 \\
$12 \mathrm{hr}$ & 17 & 23 \\
\hline
\end{tabular}

The results, depicted graphically in Figure 3, indicate that a carbonate free feed solution of uranium, at a concentration of $\sim 150 \mathrm{ppm}$, could be reduced by ion exchange to $10-20 \mathrm{ppm}$

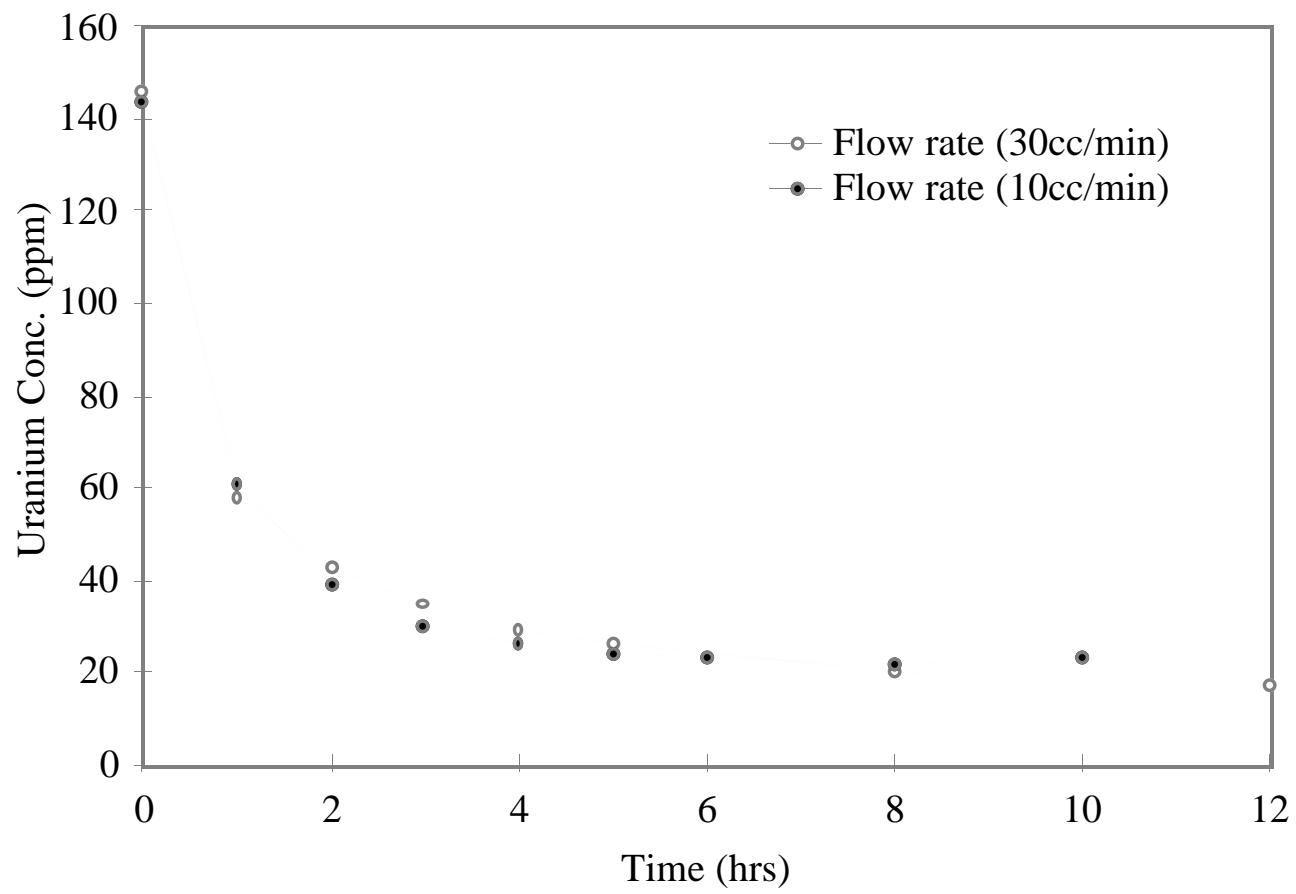

Fig. 3 Effect of Flow rate on Uranium Retension with Diphonix ${ }^{\circledR}$ Resin 
The more realistic scenario would be a waste stream which was chemically pretreated with either dithionite $\left(\mathrm{Na}_{2} \mathrm{~S}_{2} \mathrm{O}_{4}\right)$ or $\mathrm{NaOH}$ to remove most of the uranium by chemical precipitation and then polishing with ion exchange.

The following results show the excellent performance of Diphonix ${ }^{\circledR}$ as a polishing step to remove residual uranium. The feed solution, at a starting uranium concentration of $7 \mathrm{ppm}$, was pumped through the resin at 10 $\mathrm{cc} / \mathrm{min}$, with a loading capacity of $16 \%$, and the $\mathrm{pH}$ the feed solution adjusted to 5.5 .

\section{Table 9:}

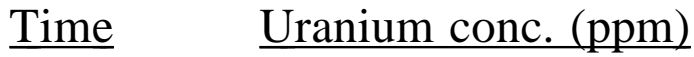

$\begin{array}{lc}0 \mathrm{hr} & 7.05 \\ 0.3 \mathrm{hr} & 2.10 \\ 0.6 \mathrm{hr} & 0.97 \\ 1.0 \mathrm{hr} & 0.27 \\ 1.5 \mathrm{hr} & 0.032 \\ 4.0 \mathrm{hr} & <0.010 \\ 6.0 \mathrm{hr} & <0.010\end{array}$

We also evaluated the loading capacity of the Diphonix ${ }^{\circledR}$ ion exchange resin to determine at what concentration uranium would breakthrough the column and exceed the loading capacity. These were followed by elution studies using ( $\left.\mathrm{NH}_{4}\right)_{2} \mathrm{CO}_{3}$ to remove the uranium from the spent column. The results are displayed in Table 10 . (Loading capacity $80 \%$, flow rate $30 \mathrm{cc} / \mathrm{min}, \mathrm{pH}$ of feed solution 5.5, uranium starting concentration 734 ppm.) 
Table 10:

Time Uranium conc. (ppm)

$0 \mathrm{hr} \quad 734$

$0.3 \mathrm{hr} \quad 543$

$0.6 \mathrm{hr} \quad 486$

$1.0 \mathrm{hr} \quad 439$

$4.0 \mathrm{hr} \quad 345$

$8.0 \mathrm{hr} \quad 349$

$14.5 \mathrm{hr} \quad 387$

Breakthrough appears at about 350 ppm Uranium under these conditions. We eluted the column in the previous experiment, using 8 bed volumes of $2 \mathrm{M}\left(\mathrm{NH}_{4}\right)_{2} \mathrm{CO}_{3}$ and were able to recover about $89 \%$ of the uranium retained on the column. This will permit reuse of the column resin and a substantial cost saving.

\section{Summary:}

The preceding experiments demonstrate a useful separation strategy using chemical reduction with $\mathrm{Na}_{2} \mathrm{~S}_{2} \mathrm{O}_{4}$ or precipitation with $\mathrm{NaOH}$ and use Diphonix ${ }^{\circledR}$ ion exchange resin to remove uranium from the Molten Salt waste stream to sub ppm levels. This method also has application to the clean up of many environmental aqueous wastes. Further studies will evaluate the performance of these methods on Thorium waste streams.

\section{Acknowledgments}

We would like to thank Michael Sharp for his help with the ICP-MS analyses.

Funding was provided by EM-30 under the Mixed Waste Management Facility project. 


\section{References:}

1 "EQ 3/6, A Software Package for Geochemical Modeling of Aqueous Systems", Thomas J. Wolery, UCRL-MA-11062, Sept. 1992.

2"The carbonate Chemistry of Uranium: Theory and Applications", McClaine, L.A., Bullwinkel, E.P., and Huggins, J.C., Proceedings of the International Conf. on Peaceful Uses of Atomic Energy, Aug 8-20, (1955), USAEC Report, Vol. VIII, P/525.

3. "Spent salt Clean-up/Recovery Process Development for Molten Salt Oxidation", Hsu, Peter C., von Holtz, Erica, Hipple, David, Summers, Leslie, and Brummond, William. in press.

4 Analytical Chemistry of Uranium, Palei, P.N. p 251, 1970.

5."Alkaline Leaching of Uranium Ores", Stephens, F.M.Jr., Macdonald, R.D., Proceedings of the International Conf. on Peaceful Uses of Atomic Energy, Aug 8-20, (1955), USAEC Report, Vol.VIII, P/520.

6. "Diphonix ${ }^{\circledR}$ Resin: A Review of its Properties and Applications", Chiarizia, R., Horwitz, E.P., Alexandratos, S.D., and Gula, M.J.. Separation Science and Technology (in press) (1996). 


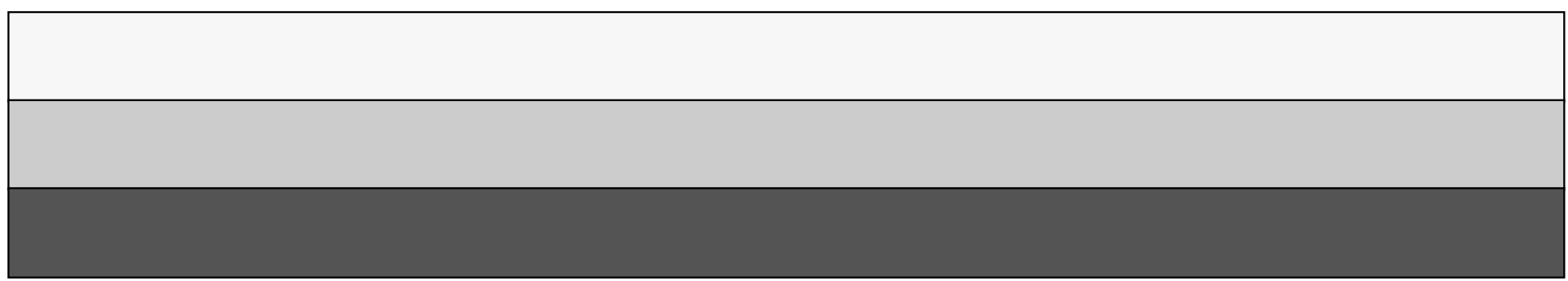

